FORUM

Submitted 03.02.2014. Approved 08.19.2014

This article is co-authored by a member of RAE's Scientific Editorial Board and was evaluated by double blind review process with impartality and independence. Scientific Editors: Gleen Morgan and Maria José Tonelli

DOI: http://dx.doi.org/10.1590/So034-759020150304

\title{
STRATEGIES FOR SUPERIOR PERFORMANCE IN RECESSIONS: PRO OR COUNTER-CYCLICAL?
}

\author{
Estratégias para desempenho superior em recessões: pro ou contra-cíclicas? \\ Estrategias para el desempeño superior en las recesiones: ¿pro o contra cíclicas?
}

\begin{abstract}
Recessions are recurring events in which most firms suffer severe impacts while others are less affected or may even prosper. Strategic management has made little progress in understanding such performance differences. In a scenario of decreased demand, intensified competition, and higher uncertainty, most firms try to survive by pro-cyclically cutting costs and investments. But firms could take advantage of undervalued resources in the market to counter-cyclically invest in new business opportunities to overtake competitors. We survey Brazilian firms in various industries about the 2008-2009 recession and analyze data using PLS-SEM. We find that while most firms pro-cyclically reduce costs and investments in recessions, a counter-cyclical strategy of investing in opportunities created by changes in the market enables superior performance. Most successful are firms with a propensity to recognize opportunities, an entrepreneurial orientation to invest, and the flexibility to efficiently implement investments.

KEYWORDS | Recession, cycle, opportunity, entrepreneurship, flexibility.
\end{abstract}

\section{RESUMO}

Recessões são eventos recorrentes nos quais a maioria das empresas sofre impactos severos enquanto outras são menos afetadas ou até prosperam. A gestão estratégica tem feito pouco progresso para entender tais diferenças de desempenho. Em um cenário de demanda reduzida, competição aumentada e muitas incertezas, a maioria das empresas tenta sobreviver cortando custos e investimentos, de maneira pró-cíclica. Mas as empresas poderiam aproveitar os recursos subestimados no mercado para investir, contra-ciclicamente, em novas oportunidades de negócios para superar a concorrência. Pesquisamos empresas brasileiras em várias indústrias sobre a recessão de 2008-2009 e analisamos dados usando PLS-SEM. Descobrimos que enquanto a maioria das empresas reduzem custos e investimento pró-ciclicamente durante as recessões, uma estratégia contra-cíclica de investir em oportunidades criadas pelas mudanças no mercado possibilitam desempenho superior. Firmas com propensão a reconhecer oportunidades, com orientação empresarial para investir e com flexibilidade para implementar os investimentos de modo eficiente são as mais bem sucedidas.

PALAVRAS-CHAVE / Recessão, ciclo, oportunidade, empreendedorismo, flexibilidade.

\section{RESUMEN}

Las recesiones son eventos recurrentes en los cuales la mayoría de las empresas sufre impactos severos mientras que otras son menos afectadas o incluso, hasta prosperan. La gestión estratégica ha tenido poco progreso para entender tales diferencias de desempeño. En un escenario de demanda reducida, mayor competencia y muchas incertidumbres, la mayoría de las empresas intenta sobrevivir recortando costos e inversiones, de manera procíclica. Pero las empresas podrían aprovechar los recursos subestimados en el mercado para invertir, contra cíclicamente, en nuevas oportunidades de negocios para superar a la competencia. Estudiamos empresas brasileñas en varias industrias sobre la recesión de 2008-2009 y analizamos datos usando PLS-SEM. Descubrimos que mientras que la mayoría de las empresas reducen costos e inversiones procíclicamente durante las recesions, una estrategia contra cíclica de inversor en oportunidades creadas por los cambios en el mercado hacen posible un desempeño mayor. Firmas con propensión a reconocer oportunidades, con orientación empresarial para invertir y con flexibilidad para implementar las inversiones de modo eficiente son las más exitosas.

PALABRAS CLAVE / Recesión, ciclo, oportunidad, emprendedorismo, flexibilidad. 


\section{INTRODUCTION}

Today's global marketplace is characterized by increased turbulence due to major shocks such as the 2008-2009 recession (Li \& Tallman, 2011; Ma, Yiu, \& Zhou, 2014), one of the most important global economic events since the Great Depression (Crotty, 2009). Economists have thoroughly studied recessions (Zarnowitz, 1985), mostly from a macroeconomic perspective to understand their causes and consequences for countries. Beyond countries, however, recessions can transform industries (Latham \& Braun, 2011) and severely affect the performance or even survival of firms (Srinivasan, Rangaswamy, \& Lilien, 2005). Most importantly, while most firms suffer severe impacts from recessions, others are less affected or even prosper (Gulati, Nohria, \& Wohlgezogen, 2010), and the reasons for such heterogeneity in firm performance are not fully understood (Geroski \& Gregg, 1997). Particularly within strategic management, there has been little investigation on how firms should deal with recessions (Bromiley, Navarro, \& Sottile, 2008).

Recessions create a scenario of decreased demand, intensified competition, and high uncertainty (Grewal \& Tansuhaj, 2001) that leads most firms to reduce their operations in a pro-cyclical strategy of cutting costs and investments in various functional areas such as production, marketing, and research and development (Tellis \& Tellis, 2009). Nevertheless, several scholars contend that firms can take advantage of lower prices to counter-cyclically invest during recessions (Navarro, Bromiley, \& Sottile, 2010). For instance, Procter and Gamble, Chevrolet, and Camel flourished during the Great Depression because they advertised heavily (Srinivasan et al., 2005).

The purpose of this research is to examine pro-cyclical and counter-cyclical strategies during recessions and their effects on performance. More specifically, we aim to: (i) investigate whether most firms pursue pro-cyclical or counter-cyclical strategies during recessions; (ii) identify firms' characteristics and capabilities that foster the use of counter-cyclical strategies; and (iii) verify whether pro-cyclical or counter-cyclical strategies enable firms superior performance during recessions.

The impact of recessions on firm performance and how firms should react is an unexplored research stream (Bromiley et al., 2008; Mascarenhas \& Aaker, 1989). Our study contributes to the strategy literature in business cycle management. In particular, we answer a call for scholars to analyze how firms absorb and react to economic downturns (Kaytaz \& Gul, 2014; Latham \& Braun, 2008) and to examine organizational factors (Srinivasan, Lilien, \& Sridhar, 2011) that influence investment preferences in these environments (Zona, 2012). To our knowledge, this is the first study to propose an integrative model with several variables to investigate recessions and to empirically test it with survey data.

\section{RECESSIONS AND THEIR CONSEQUENCES TO FIRMS}

Recessions are recurring events, part of business cycles comprising periods of economic growth followed by periods of economic contraction (Latham \& Braun, 2011). They are technically defined as a decrease in real gross domestic product for two consecutive quarters (Claessens \& Kose, 2009). Economic theories try to explain recessions, but with a country-wide perspective. In this paper, we take a business approach and focus on three important consequences of recessions for firms - change in demand patterns, increase in competition, and increase in uncertainty.

First, recessions reduce the demand for most firms' products and services (Srinivasan et al., 2011). This is due to lower employment, which leads to decreased disposable income, and it is also due to decreased consumption confidence created by job insecurity (Dutt \& Padmanabhan, 2011; Hall, 2005). Besides this general demand reduction, recessions alter demand patterns (Mansoor \& Jalal, 2011) - the variability in customer populations and preferences. The impact of recessions varies among consumers of different income levels, with lower income classes suffering the most (Grusky, Western, \& Wimer, 2011). The impact of recessions also varies among industries and segments. Consumers become more price conscious (Hampson \& McGoldrick, 2013) and "downtrade" to cheaper items and stores (Ang, Leong, \& Kotler, 2000; Kaytaz \& Gul, 2014) or substitutes (Dutt \& Padmanabhan, 2011; Srinivasan et al., 2011). Discretionary such as leisure and luxury items suffer more (Mansoor \& Jalal, 2011; Zurawicki \& Braidot, 2005), while necessities such as housing and health care are less affected (Dutt \& Padmanabhan, 2011; Kamakura \& Du, 2012). The demand for durable goods is particularly reduced due to credit restrictions (Gertler, Kiyotaki, \& Queralto, 2012) and the possibility of purchase postponement (Lamey, Deleersnyder, Steenkamp, \& Dekimpe, 2012).

Second, recessions change the market competitive intensity - the degree of competition a firm faces (Grewal \& Tansuhaj, 2001). Demand contraction creates pressure for firms to cut prices in order to keep sales level (Kaytaz \& Gul, 2014; Kamakura \& Du, 2012), which tends to increase rivalry among industry players (Porter, 1979). In addition, new demand patterns change relationships, power balance, and trust between firms and their competitors, customers, and suppliers (Apaydın, 2011; Lamey et al., 2012), also leading to higher rivalry. 
Third, recessions generate uncertainties (Latham \& Braun, 2008; Parnell, Dent, O’Regan, \& Hughes, 2012). Although the direction of changes in demand and pricing is mostly known, their levels and timing are difficult to predict. As recessions vary greatly in amplitude and duration (Zarnowitz, 1985), firms cannot foresee for how long consumers will postpone purchases or for how long competitors will resist the pressure to cut prices.

\section{THEORY DEVELOPMENT AND HYPOTHESES}

The scenario of decreased demand, intensified competition, and high uncertainty brings severe negative impacts to most firms, while some others are less affected or even prosper in recessions (Dutt \& Padmanabhan, 2011). We study the strategies, pro-cyclical or counter-cyclical, that enable firms to have superior performance. By superior performance, we mean either of two situations. In the first case, a firm may be less affected than competitors by the negative impacts of the recessionary environment, even though its absolute performance may decline compared to the moment prior to the recession. In the second case, which is less common, a firm may benefit from the recession more than competitors and even improve its performance.

Especially in severe cases, recessions represent risk to the survival of firms (Parnell et al., 2012). Forced to rethink their strategies (Geroski \& Gregg, 1997), firms may choose various courses of action. They may adopt a pro-cyclical behavior of cutting costs and expenditures, react with a counter-cyclical behavior of increasing investments, respond with a combination of both, or even do nothing while waiting for macroeconomic recovery.
Most firms adopt a pro-cyclical strategy. During recessions, profits decrease (Beaver, 2002), bank credit is restricted or more expensive (Ivashina \& Scharfstein, 2010), and equity markets typically “dry up” (Latham \& Braun, 2008). With limited funding, firms have to reduce costs, bypass projects, and cut investments (Campello, Graham, \& Harvey, 2010).

But several firms realize that just surviving the storm is not enough and adopt a counter-cyclical strategy. Despite an undeniable need to preserve short-term cash, firms must invest for future growth, as some long-term industry trajectories and related firm objectives should not change (Dye, Sibony, \& Viguerie, 2009). Firms can take advantage of undervalued assets in the market (Mascarenhas \& Aaker, 1989) to develop new business opportunities, differentiate themselves, and overtake competitors (Nunes, Drèze, \& Han, 2010). They are able to both achieve immediate returns (Srinivasan et al., 2005) and prepare for long-term success (Franke \& John, 2011).

While several authors recommend counter-cyclical strategies, empirical tests of their benefits are limited. Reviews of prior studies are provided by Latham \& Braun (2011), who note a positive link between counter-cyclical strategies and performance, and by Srinivasan et al (2011), who warn about mixed results. Most importantly, except for Navarro et al (2010) and Gulati et al (2010), the majority of research on the topic limits the analysis to one area: marketing, R\&D or capital expenditures. To fill this gap, we assess firms' concomitant responses to recessions in various types of investments. Adjusting the model proposed by Navarro et al (2010), we study the cyclical strategies pursued by firms grouped in three independent areas (supply, demand, and capital). Our framework of hypotheses is shown in Figure 1.

\section{Figure 1. Framework of hypotheses}

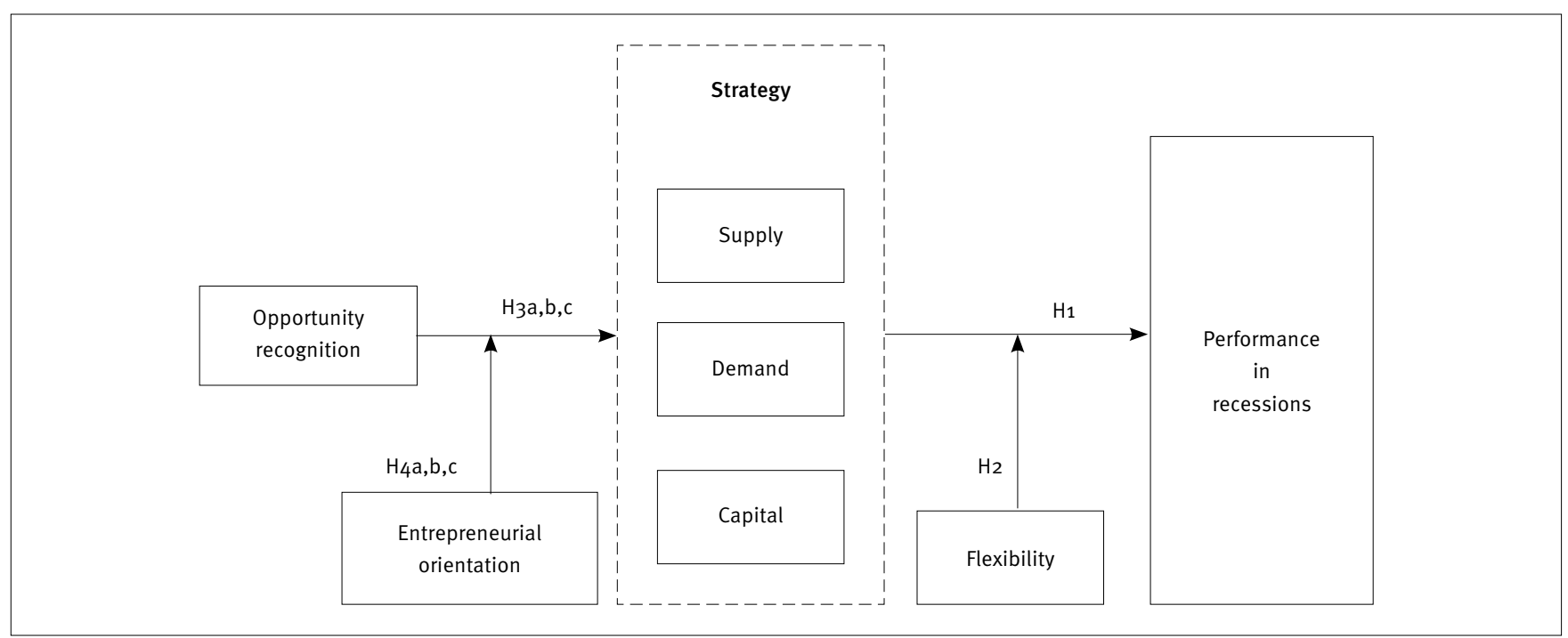




\section{Supply strategies}

In line with Navarro et al (2010), our supply dimension comprises three subdimensions: staffing, production, and purchasing.

Firms' staffing strategies tend to be pro-cyclical. Misleading expectations during economic expansions (Gore, 2010) result in overestimated sales, production, and staffing needs. Entering recessions, firms try to stabilize their finances through efficiency measures such as employee layoffs (Latham \& Braun, 2011). Nevertheless, a counter-cyclical staffing strategy may be beneficial in two ways. First, layoff avoidance boosts the usually low employee morale during downturns. Instead of worrying about job security (Gulati et al., 2010), employees can focus on their tasks and maintain productivity. They also tend to continue with the firm during recovery, which prevents rehiring at increased costs. Second, high recession unemployment (Hall, 2005) raises the pool of qualified labor available in the market, which allows hiring at lower wages (Mascarenhas \& Aaker, 1989).

Firms' production strategies are also usually pro-cyclical. As demand decreases, sales flatten, and finished goods inventories pile up during recessions, firms cut production (Zarnowitz, 1985). However, a counter-cyclical strategy of increasing production may be recommended to avoid product shortages that prevent revenue opportunities and market share gain at the beginning of the recovery (Bromiley et al., 2008). Furthermore, during recessions, firms can take advantage of lower labor costs and lower materials costs.

Firms' purchasing strategies are usually also pro-cyclical. Appropriate inventory levels depend on accurate sales forecasts. Again, misleading expectations during upturns lead to overestimated sales and production forecasts, resulting in an increase in raw materials purchases. Thus, firms enter recessions with excess inventories (Navarro et al., 2010). As recessions reduce demand and sales, firms cut production and use fewer materials, so inventories increase even further. Then, the intuitive measure is to reduce purchases to lower inventory costs (Apaydin, 2011). Nonetheless, a counter-cyclical strategy of raising purchases during recessions may be recommended. Firms can take advantage of lower prices and possibly better credit terms from suppliers to guarantee inputs for which there may be shortages after suppliers cut production.

\section{Demand strategies}

Our demand dimension comprises marketing investments, pricing, and R\&D investments. To Navarro et al (2010), we added the R\&D subdimension since investments in marketing and in R\&D usually accompany one another (Gulati et al., 2010).
Academic research has documented marketing pro-cyclical behavior. Advertising and promotions increase during expansions and are cut in contractions (Srinivasan et al., 2011), when most firms view them as dispensable luxuries (Apaydin, 2011). However, several authors recommend that companies focus on marketing and be more aggressive to capitalize on the changes in consumption patterns during downturns (Ang et al., 2000). As most firms reduce their advertising in recessions, media owners offer lower rates. Hence, firms that advertise achieve higher return on their investments (Apaydin, 2011).

Firms' cyclical behavior in pricing is less clear than in marketing investments. There is pressure for firms to cut prices (Ang et al., 2000; Kamakura \& Du, 2012) to keep sales level, since as a result of lower income, consumers reduce consumption, become more price conscious, and "downtrade" to cheaper items. Nevertheless, empirical evidence indicates that most firms do not change (Geroski \& Gregg, 1997) or even raise prices during recessions (Lamey et al., 2012; Mansoor \& Jalal, 2011). A recommendation for cyclical strategy is also complex. Economic theory suggests that firms respond to reduced demand by lowering prices. But a marketing perspective warns that pricing cuts may reduce brand equity and hinder long-term positioning (Latham \& Braun, 2011). Moreover, consumers will expect lower prices to continue after economic recovery, which would reduce long-run revenues (Apaydin, 2011).

The pro-cyclical innovation behaviors (Lamey et al., 2012) and R\&D (Latham \& Braun, 2011) have been documented by academic research. Pressed to control costs to maintain liquidity during recessions, firms reduce R\&D programs, thereby increasing short-term cash flow (Srinivasan et al., 2011). However, firms that add new features and upgrade their products to match new demand patterns in downturns may perform better (Apaydin, 2011). Furthermore, firms can take advantage of lower costs during recessions to reach higher returns on their R\&D investments (Gulati et al., 2010).

\section{Capital strategies}

Our capital dimension comprises credit policy, capital expenditures in fixed assets, and acquisitions. From Navarro et al (2010), we have dropped the capital financing subdimension, as those authors obtained high cross-loadings for it in their factor analysis.

Firms tend to follow a pro-cyclical credit policy. As the recession hits various industries, most businesses face cash flow challenges due to lower profits (Beaver, 2002) and reduced bank credit (Ivashina \& Scharfstein, 2010). It becomes more common for customers to default and request loosening of pay- 
ment terms (Ang et al., 2000). To keep sales at a reasonable level, firms usually succumb to customers' pressures and expand their credit (Mascarenhas \& Aaker, 1989). However, during recessions, firms should carefully monitor customers' performances and adjust credit policies, accelerating collections and tightening credit terms to reduce the risk of nonpayment (Dye et al., 2009).

Firms' pro-cyclical patterns of expenditures in fixed assets are observed by the capital investment literature (Navarro et al., 2010). Geroski \& Gregg (1997) report that investment in plants and equipment usually falls markedly in recessions, more than investment in intangibles (like marketing and R\&D). Similarly, Latham \& Braun (2011) mention that firms often sell assets to stabilize their finances. Nonetheless, this pro-cyclical pattern can lead to overinvestments and consequent excess capacity during the upturn, followed by exaggerated cuts and undercapacity in recessions (Apaydin, 2011). On the contrary, firms could take advantage of lower prices during recessions to invest in property, plants, and equipment in order to guarantee adequate capacity and modern equipment; this would help them offer superior products and gain market share both in the recovery (Bromiley et al., 2008) and during the downturn (Gulati et al., 2010).

Acquisitions are most likely pro-cyclical (Geroski \& Gregg, 1997), as firms tend to buy during expansions and sell during recessions. Recession-driven changes in market structure (Hampson \& McGoldrick, 2013) may alter assets relevance and value, making many of them available for sale in a firm's businesses portfolio. As firms try to preserve cash, divestitures are more common than acquisitions (Latham \& Braun, 2011). Complementing this rationale from the opposite perspective, it is difficult for a potential acquirer to convince its management of the viability of acquisitions, given the low growth projections for target firms (Navarro et al., 2010). However, counter-cyclical acquisitions in recessions may be a better idea, as prices tend to be lower for two reasons. First, as firms in financial trouble put parts of their businesses for sale (Campello et al., 2010), the number of takeover candidates increases (Franke \& John, 2011), reducing prices. Second, potential acquirers have less cash available, decreasing the likelihood of overpayment for target firms (Ma et al., 2014), a problem that is common in upturns. Therefore, firms that counter-cyclically make acquisitions during recessions tend to benefit from a lower price-to-value rate (Bromiley et al., 2008).

In sum, during recessions, firms can take advantage of higher availability of qualified resources at lower prices to make counter-cyclical investments in supply-, demand-, and capital-related areas. Hence, we offer the following hypothesis:
$\mathrm{H}_{1}$ : Counter-cyclical strategies of increased investments in supply-, demand-, and capital-related areas during recessions lead to superior change in performance.

\section{The moderating effect of flexibility}

The success of counter-cyclical investments in recessions depends on firms' capabilities. We argue that flexibility helps firms efficiently implement counter-cyclical strategies that enable superior performance.

Flexibility is defined as a firm's ability to rapidly change its policies and procedures to adapt to changes in the environment that bring uncertainty and significantly impact performance (Aaker \& Mascarenhas, 1984; Rowe \& Wright 1997). We believe in a strong fit between flexibility and recessionary environments, as recessions bring changes, uncertainty, and instability (Grewal \& Tansuhaj, 2001; Ma et al., 2014), a context that demands flexibility.

Recessions change demand patterns, behavior, and relative power of competitors and suppliers, as well as the industry's regulative environment. Opportunities that arise for counter-cyclical investments are related to this new market structure that requires adaptations in products, resources, and processes.

In mild recessions, changes in market structure are limited, and exploitation of opportunities probably requires no more than switching focus among segments. Operational flexibility to adjust production schedules and product mix is useful and usually sufficient for implementation of the new, counter-cyclical strategy.

In severe recessions, market changes are deeper, and exploitation of opportunities requires different resources. But new resource acquisition or development are restricted by lower availability of cash and time constraints. Thus, strategic flexibility becomes important for quick relocation of resources from their original departments and adaptation to new purposes (Wang, 2008) and also for effective coordination of this new resource configuration (Zhou \& Wu, 2010). This way, the firm can efficiently implement the new, counter-cyclical strategy and experiment with new products (McGrath, 1999) to reach other consumers.

In another scenario, drastic and prolonged recessions bring more radical and lasting transformations to the market (Zurawicki \& Braidot, 2005). Firms need to transform their activities (McGahan, 2004), not simply adjust the product mix or reconfigure current resources. Structural flexibility is necessary to change decision and communication processes and create new organizational structures. 
In sum, operational, strategic, and structural flexibility allow changes in firms' products, resources, and processes. Thus, the more a firm is flexible, the more efficient is the implementation of investments in supply-, demand-, and capital-related areas to improve performance. Hence, we offer the following hypothesis:

$\mathrm{H}_{2}$ : Flexibility moderates the relationship between strategy and performance such that increased flexibility strengthens the positive effect of a counter-cyclical strategy of investments on the change in performance during recessions.

Despite the advantages of investments during recessions, only a few firms adopt this counter-cyclical strategy. We claim that two firm characteristics increase their probability of counter-cyclically investing - opportunity recognition and entrepreneurial orientation.

\section{The effect of opportunity recognition}

Different firms follow different strategies during recessions, partly because they differ in the extent to which they view recessions as threats or opportunities (Latham \& Braun, 2011). These different views depend mostly on how employees fit information received into their cognitive structures to interpret the environment (Plambeck \& Weber, 2010). Similar to Srinivasan et al (2005), we define opportunity recognition in recessions as a firm's propensity to create or recognize opportunities arising from the recession.

In the recessionary context of uncertainty, opportunities are not obvious to everyone (McGrath, 1999). A propensity to recognize opportunities is a consequence of employees having a mindset to sense and capture benefits from changes in the environment (McGrath \& MacMillan, 2000). Only alert individuals can identify when and where new knowledge can be applied to create feasible goods and services (Ireland, Hitt, \& Sirmon, 2003). And only those firms that perceive these opportunities find interesting projects that are worth investing in. Hence, we offer the following hypothesis:

$\mathrm{H}_{3}$ : Opportunity recognition in recessions increases firms' use of counter-cyclical strategies of investments in supply- $\left(\mathrm{H}_{3} \mathrm{a}\right)$, demand- $\left(\mathrm{H}_{3} \mathrm{~b}\right)$, and capital-related $\left(\mathrm{H}_{3} \mathrm{C}\right)$ areas during recessions.

\section{The effect of entrepreneurial orientation}

A second characteristic of firms that may increase their probability of counter-cyclically investing during a recession is en- trepreneurial orientation (EO). Entrepreneurial concepts fit the recessionary environment, as they are usually associated with disruptions in the economy (Hill \& Mudambi, 2010), such as those created by recessions.

Srinivasan et al (2005) suggest that firms vary not only in the extent to which they see opportunities within these disruptions, but also in their ability to capitalize on a perceived opportunity. We argue that this ability depends on a willingness to act, part of a firm's EO in its three dimensions. The proactiveness dimension is essential because if a firm is not proactive, it will not take action to exploit the opportunity. An entrepreneurial firm anticipates future needs (Lumpkin \& Dess, 1996) and moves ahead quickly, even with incomplete information (Green, Covin, \& Slevin, 2008).

The innovativeness dimension is important because if the firm does not favor creative change, an integral part of innovativeness, it will not take the necessary steps to exploit the opportunity (Ireland et al., 2003). Entrepreneurs creatively engage with the opportunities presented by the changing environment (Gupta, MacMillan, \& Surie, 2004).

Finally, the risk-taking dimension is fundamental because if the firm does not have risk-taking propensity, it will not invest in opportunities, whose outcomes are always associated with uncertainty and risky returns. The uncertainty of recessions increases risk aversion (Muurlink, Wilkinson, Peetz, \& Townsend, 2012), but in an entrepreneur's cognition, risk concerns are overruled by opportunity recognition (Wright, Hoskisson, Busenitz, \& Dial, 2000).

Thus, the more a firm is entrepreneurially oriented, the more it will be willing to counter-cyclically invest to seize these opportunities. All those arguments hold for supply-, demand-, and capital-related areas. Hence, we offer the following hypotheses:

\footnotetext{
$\mathrm{H}_{4}$ : Entrepreneurial orientation moderates the relationship between opportunity recognition and strategy in recessions such that increased entrepreneurial orientation strengthens the positive effect of opportunity recognition on firms' adoption of counter-cyclical strategies of investing in supply- $\left(\mathrm{H}_{4} \mathrm{a}\right)$, demand- $\left(\mathrm{H}_{4} \mathrm{~b}\right)$, and capital-related $\left(\mathrm{H}_{4} \mathrm{C}\right)$ areas during recessions.
}

\section{METHOD}

All hypotheses were tested using data from Brazilian firms on the 2008-2009 global recession. It reached most developed and developing countries (Gore, 2010), becoming the most severe recession since the 1929 financial crash (Crotty, 2009). Brazil is a good setting for our investigation because it was sharply affected by the crisis, accumulating $4 \%$ GDP contraction from 
the fourth quarter of 2008; but most firms recovered by the second quarter of 2009 (Galveas, 2009; Pochman, 2009), which allowed for good comparisons by the time of our survey.

Our sample includes firms of various sizes and from various industries. Data were collected from a survey in 2011-2012 directed to finance or planning managers of publicly traded firms. The questionnaire was developed in Portuguese, the native language of the respondents, with fivepoint, Likert-type questions selected from several validated scales. To prevent common method bias, we have spread the items that measure a same construct throughout the questionnaire and included reverse-coded items (Podsakoff, MacKenzie, \& Podsakoff, 2012). Moreover, our hypotheses include moderation effects, which are not affected by common method variance (Siemsen, Roth, \& Oliveira, 2010). The questionnaire was discussed with executives and pretested with executive MBA students who typically had 10 years of experience. All respondents received explanations about the research purpose and confidentiality of answers. Questionnaire items are shown in Table 1.

\section{Table 1. Measurement items and indices of the reflective constructs}

(continue)

\begin{tabular}{|c|c|c|c|}
\hline Reflective constructs and their items & Load & CR & AVE \\
\hline Change in performance & & 0.94 & 0.76 \\
\hline Operating revenue & 0.90 & & \\
\hline Operating profit & 0.94 & & \\
\hline Market share & 0.69 & & \\
\hline
\end{tabular}

\section{Opportunity recognition \\ Particulary about the 2008-2009 recession:}

Our firm's management treated the downturn more like an opportunity than as a threat.

Our plans for the downturn basically involved hunkering down and riding out of the recession. $(R)$

We viewed this downturn as an opportunity to leapfrog over our competitors.

\begin{tabular}{l|l|l|l} 
& 0.81 & 0.58 \\
\hline & & & \\
\hline 0.90 & & \\
\hline 0.63 & & \\
\hline 0.75 & & \\
\hline
\end{tabular}

\section{Innovativeness}

Innovative ideas are well accepted in our firm.

Our performance appraisal system rewards people for new ideas and process improvement.

Our firm accepts errors as a way of learning

\begin{tabular}{|c|c|c|}
\hline & 0.75 & 0.50 \\
\hline 0.72 & & \\
\hline 0.75 & & \\
\hline 0.64 & & \\
\hline
\end{tabular}

\section{Proactiveness}

Our firm typically initiates actions which competitors then respond to.

Particularly about the 2008-2009 recession:

We were very proactive in developing plans to counter the downturn.

We responded more quickly to the market changes caused by the downturn than our competitors.

\begin{tabular}{|c|c|c}
\hline & 0.82 & 0.60 \\
\hline 0.57 & & \\
\hline- & & \\
\hline 0.90 & & \\
\hline 0.83 & & \\
\hline
\end{tabular}

\section{Risk taking}

The top managers of this firm believe that bold strategies are required to achieve our business objectives.

In general, people at our firm accept changes promptly.

\begin{tabular}{|l|l|l}
\hline & 0.72 & 0.57 \\
\hline 0.71 & & \\
\hline 0.80 & & \\
\hline
\end{tabular}

\section{Creativity}

Our employees know how to improvise when necessary.

Our firm has great ability to adress new situations through new ideas of using the resources at hand.

In our firm, people are encouraged to resolve problems in creative ways.

\begin{tabular}{l|l|l} 
& 0.81 & 0.59 \\
\hline 0.72 & & \\
\hline 0.80 & & \\
\hline 0.79 & & \\
\hline
\end{tabular}


Table 1. Measurement items and indices of the reflective constructs

(conclusion)

\section{Reflective constructs and their items}

\section{Spontaneity}

In our firm, actions are always carefully planned before execution. ( $R$ )

To respond to unexpected events, our firm encourages balance between established plans and flexibility.

\begin{tabular}{|c|c|c|}
\hline Load & CR & AVE \\
\hline & 0.76 & 0.62 \\
\hline 0.71 & & \\
\hline 0.85 & & \\
\hline
\end{tabular}

\begin{tabular}{|c|c|c|c|}
\hline Operational flexibility & & 0.79 & 0.56 \\
\hline \multicolumn{4}{|l|}{ In responding to changes in the business environment, our strategy emphasys flexibility... } \\
\hline in the allocation of production resources to manufacture a broad range of products or services. & 0.82 & & \\
\hline in the design of products or services to support a broad range of applications. & 0.82 & & \\
\hline
\end{tabular}

\begin{tabular}{|c|c|c|c|}
\hline Strategic flexibility & & 0.78 & 0.55 \\
\hline \multicolumn{4}{|l|}{ In responding to changes in the business environment, our firm... } \\
\hline is able to reconfigure its organizational resources to support different strategies. & 0.74 & & \\
\hline \multicolumn{4}{|l|}{ In responding to changes in the business environment, our strategy emphasizes flexibility... } \\
\hline in the allocation of marketing resources to market a broad range of products or services. & 0.78 & & \\
\hline
\end{tabular}

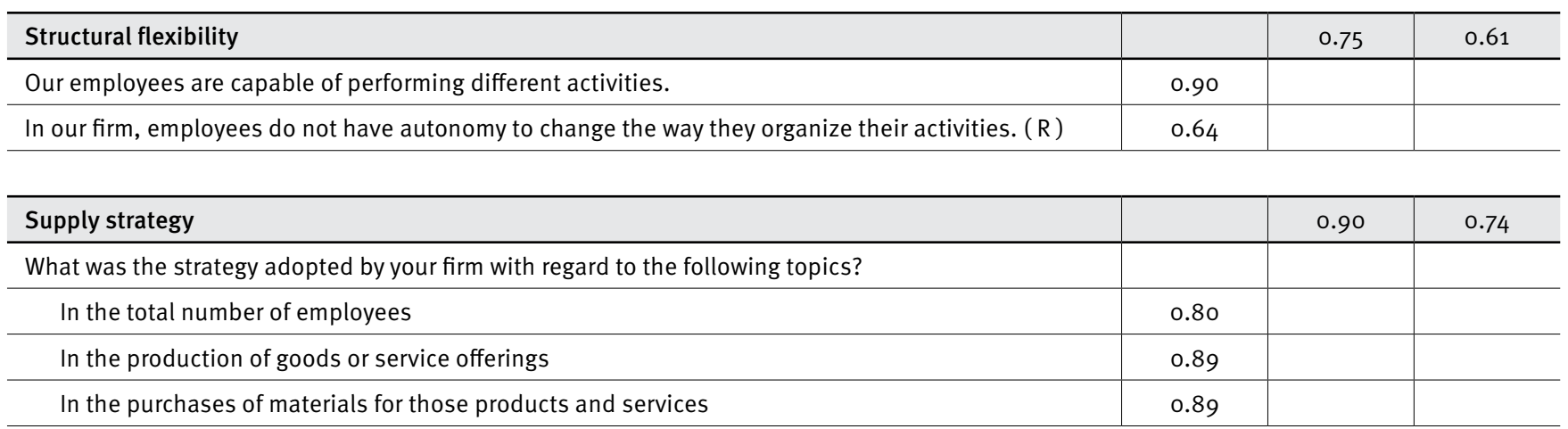

\begin{tabular}{l|c|c}
\hline Demand strategy & 0.60 & \\
\hline What was the strategy adopted by your firm with regard to the following topics? & & \\
\hline In research and development invstiments & 0.89 & \\
\hline In marketing investments & 0.89 & \\
\hline In product prices, on average & 0.48 & \\
\hline
\end{tabular}

\begin{tabular}{l|c|c}
\hline Capital strategy & 0.53 & 0.77 \\
\hline What was the strategy adopted by your firm with regard to the following topics? & & \\
\hline In the ease of credit offered to clients & 0.71 & \\
\hline In fixed assets investments & 0.80 & \\
\hline In investments in other firms & 0.68 & \\
\hline
\end{tabular}

$(\mathrm{R})$ : Item is reverse coded.

CR: Composite reliability.

AVE: Average variance extracted.

All algorithm calculations based on path weighting scheme. 


\section{Measures and instrument}

Our study has four dependent variables. The first is the change in performance during the recession (CHPERF), measured with five indicators that together represent both the short-term and longterm perspectives: cash flow, market share, operating revenue, operating profit, and net profit. Respondents were asked to select, from a five-point Likert-type scale, how each of the five indicators was affected by the recession. We have decided to use subjective measures, as they preserve confidentiality of respondents and facilitate comparisons across multiple industries (Gruber, Heinemann, Brettel, \& Hungeling, 2010). They have also been widely used (Venaik, Midgley, \& Devinney, 2005) and tend to have high convergent validity with objective measures (Worren, Moore, \& Cardona, 2002), available only for some of our firms.

The other three dependent variables are the strategies in supply-, demand-, and capital-related areas followed by firms during recession. Most items were selected and adapted from Navarro et al (2010) and one item was created based on Gulati et al's (2010) findings. Respondents were asked to evaluate whether firms, in an attempt to cope with the recession, increased or decreased investments in each of the three areas' subdimensions.

Our study has four independent variables. Opportunity recognition in recession (OPP) was measured using three items selected from Srinivasan et al (2005). Entrepreneurial orientation (EO) was measured in three dimensions with 10 items selected from Anderson, Covin, \& Slevin (2009) and Srinivasan et al (2005) and adapted to our context of crisis. Both questionnaires were developed based on the well-recognized scale by Covin \& Slevin (1989). Flexibility (FLEX) was measured with 12 items for its three dimensions. Ten items were selected and adapted from Zhou \& Wu (2010), Nadkarni \& Narayanan (2007), and Verdú-Jover, Lloréns-Montes, \& García-Morales (2006). The other two items were created based on theory. Cyclical strategy (STRAT) was created as a composite index of its three areas.

We control firm size, age, financial slack, and industry. For performance testing, we also control exports, opportunity recognition, and improvisation capability. These variables were indicated in prior studies as important in recessions or situations of change.

\section{RESULTS}

Our preliminary data analysis did not find abnormal patterns of answers. Our final sample comprises 111 usable questionnaires, which passes the minimum sample criteria as proposed by Hair, Ringle, \& Sarstedt (2011) for partial least squares (PLS), the method of analysis we have selected. Harman's single-factor test (Podsakoff \& Organ, 1986) has indicated that common method bias was limited.

We have developed distinct sets of analyses to address our objectives. First, to investigate whether most firms pursue pro- or counter-cyclical strategies during recessions, we looked at the percentages of answers, as shown in Table 2. Our results indicate that the majority pursued a pro-cyclical strategy of reductions in supply-related areas, particularly decreasing purchases (56.9\% of respondents) and cutting personnel (52.3\%), but also reducing production (49.1\%). In all three cases, reductions were small. Regarding demand, reduction was the predominant behavior in R\&D (44.3\%) and marketing (43.2\%) investments, while no change was the most common behavior in pricing $(49.1 \%)$. Nonetheless, among those firms that did change prices, a higher percentage reduced (31.8\%) rather than increased (19.1\%) prices. Again, reductions were small in all three cases.

In capital-related areas, no change was the prevailing behavior, particularly in acquisitions $(58.4 \%)$ and credit policy (54.5\%), but also in fixed assets ( $43.7 \%$ ), although pro-cyclical reductions in fixed assets were also reported by several firms (42.7\%). Among those firms that changed strategies, a higher percentage reduced rather than increased investments in all three capital-related areas. Reductions were small in credit policy to clients, but large for fixed assets and acquisitions.

Few firms adopted counter-cyclical strategies during the recession. In general, investments were small increases in demand-related areas, most commonly in the form of a price increase. Firms that adopted counter-cyclical moves share particular characteristics and capabilities, which we discuss next.

To address both our second objective of identifying firms' characteristics and capabilities that foster the use of counter-cyclical strategies and our third objective of verifying the effect of cyclical strategies on performance, we have relied on variance-based structural equation modeling (SEM)-PLS. We have tested our eight hypotheses using the SmartPLS software (Ringle, Wende, \& Will, 2005). PLS is the fitting type of SEM here because it is appropriate for models that use a combination of formative and reflective measures (Gruber et al., 2010) and deal with non-normal data and small samples (Ringle, Sarstedt, \& Straub, 2012). PLS-SEM is popular in various disciplines (Hair, Ringle, \& Sarstedt, 2012) and has been growing in strategy (Hulland, 1999), to which it is particularly suited (Robins, 2012). Our analysis is divided in two parts - measurement model and structural model - and follows the acceptance criteria and reporting suggestions described by Ringle et al (2012) and Hulland (1999). 


\section{Measurement model}

All first-order constructs in our model were measured by reflective indicators, whose details are shown in Tables 1 and 3 . Indicators have good reliability (Tsang, 2002), particularly considering early stages of theory development (Hair et al., 2011; Hulland, 1999); this is true except for the pricing indicator, kept for conceptual relevance (Schotter \& Beamish, 2013) and consistency with Navarro et al (2010). Constructs have adequate reliability (composite reliabilities higher than 0.70 ) and discriminant validity, as the average variances extracted are higher than squared correlations between constructs (Crossland \& Hambrick, 2011; Fornell \& Larcker, 1981).

Table 2. Strategy adopted by Brazilian firms - \% of usable answers

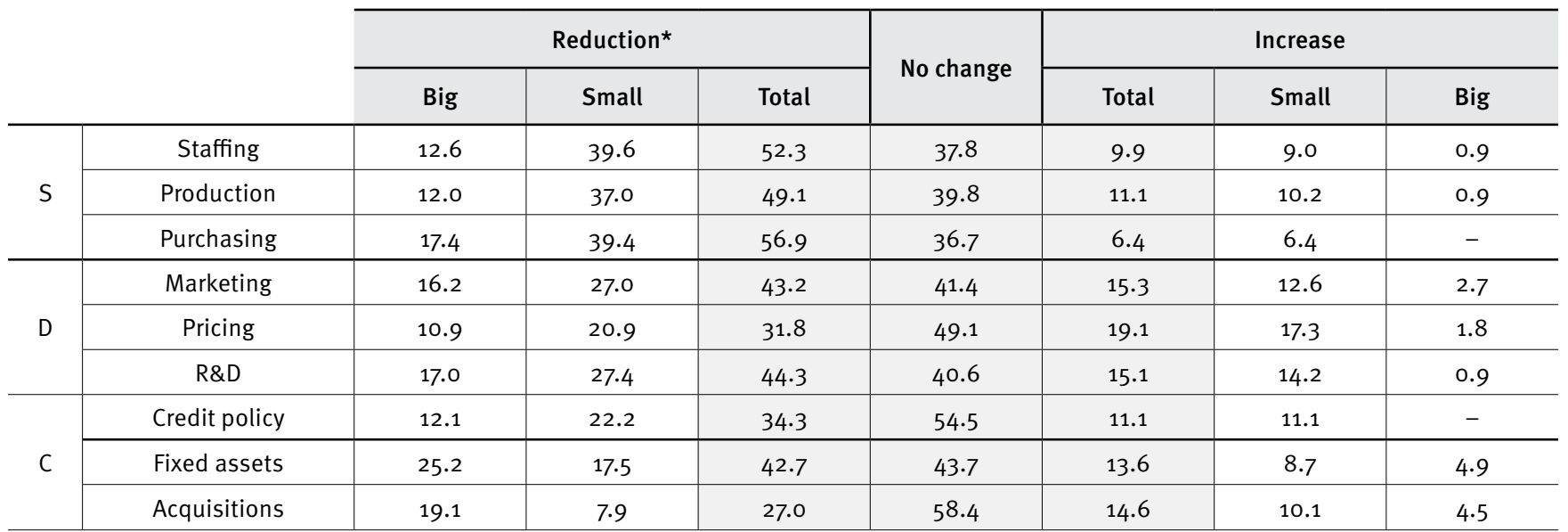

* Can be either a reduction in investments, or the case of lay-offs, sale of assets, or divestitures.

Table 3. Descriptive statistics and correlations

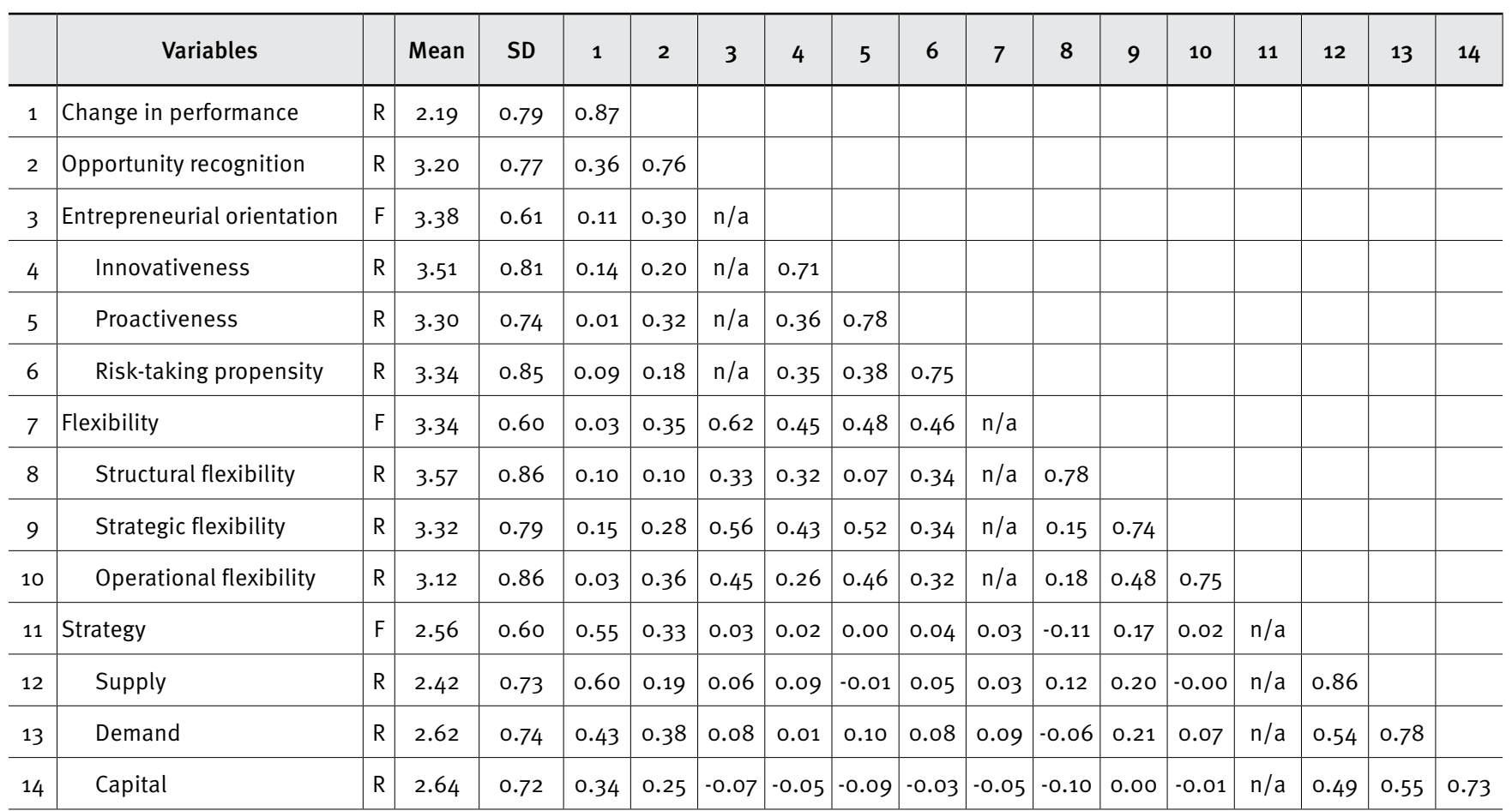

Note: Square roots of AVEs in the diagonal, correlations off-diagonal.

$\mathrm{R}=$ Reflective construct; $\mathrm{F}=$ Formative construct.

$\mathrm{SD}=$ Standard deviation

$\mathrm{n} / \mathrm{a}=$ Not applicable for formative constructs and their dimensions. 
Second-order constructs strategy, entrepreneurial orientation, improvisation capability, and flexibility, shown in Tables 3 and 4 , were measured by formative indicators. Significant t-values and high coefficients suggest that indicators sufficiently contribute to forming their constructs. Variance inflation factors lower than 3 indicate that multicollinearity is not a problem (Gruber et al., 2010).

\section{Table 4. Measurement indices of formative constructs}

\begin{tabular}{|c|c|c|c|}
\hline Formative constructs & Weight* & t-value $e^{\star \star}$ & VIF*** \\
\hline Entrepreneural orientation & & & 1.24 \\
\hline Innovativeness & 0.41 & $6.81+++$ & \\
\hline Proactiveness & 0.59 & $9.22+++$ & \\
\hline Risk taking & 0.29 & $6.25+++$ & \\
\hline Improvisation capability & & & 1.13 \\
\hline Creativity & 0.77 & $12.35+++$ & \\
\hline Spontaneity & 0.42 & $6.09+++$ & \\
\hline Flexibility & & & 1.22 \\
\hline Operational flexibility & 0.55 & $8.79+++$ & \\
\hline Strategy flexibility & 0.54 & $8.97+++$ & \\
\hline Structural flexibility & 0.18 & $2.47++$ & \\
\hline Strategy & & & 1.58 \\
\hline Supply & 0.53 & $13.64^{+++}$ & \\
\hline Demand & 0.37 & $14.04+++$ & \\
\hline Capital & 0.30 & $10.52+++$ & \\
\hline
\end{tabular}

* Algorithm calculations based on path weighting scheme.

** All calculations based on bootstrapping with 1,000 samples or more and individual sign changes.

$\star \star \star$ Average variance inflation factor.

+ significant at $10 \%$.

++ significant at $5 \%$.

+++ significant at $1 \%$.

\section{Structural model results}

Unlike covariance-based SEM, PLS-SEM does not rely on fit indices (such as chi-square) that compare observed and predicted covariance matrices (Hair et al., 2011; Hulland, 1999). PLS-SEM models are instead evaluated based on variance explained indices such as $\mathrm{R}^{2}$, as well as the value and significance of measurement and path coefficients (Ringle et al., 2012).

We have divided our results into two analysis sets. The first, shown in Table 5, addresses the influence of cyclical strategies on the change in performance. Model 1 shows the direct effect of control variables as our starting point. Model 2 adds the direct effects of all independent variables. Strategy has a positive, significant path coefficient $(b=+0.44)$, confirming that a counter-cyclical strategy of higher investments enables superior performance, which supports $\mathrm{H}_{1}$. Model 3 adds the indirect effect of flexibility. The $\mathrm{R}^{2}$ calculation at $51 \%$ indicates that our model is a good predictor of performance in recessions. Moreover, the $22 \%$ increase in $\mathrm{R}^{2}$ versus Model 1 confirms that our theorized variables offer important contribution to that prediction. Model 3 also indicates that the moderating effect of flexibility on the relationship between strategy and change in performance has a positive, significant path coefficient $(b=+0.25)$. This result confirms that increased flexibility strengthens the positive effect of strategy on performance and supports $\mathrm{H}_{2}$. 
Table 5. Results of the PLS structural model analysis - dependent variable: change in performance

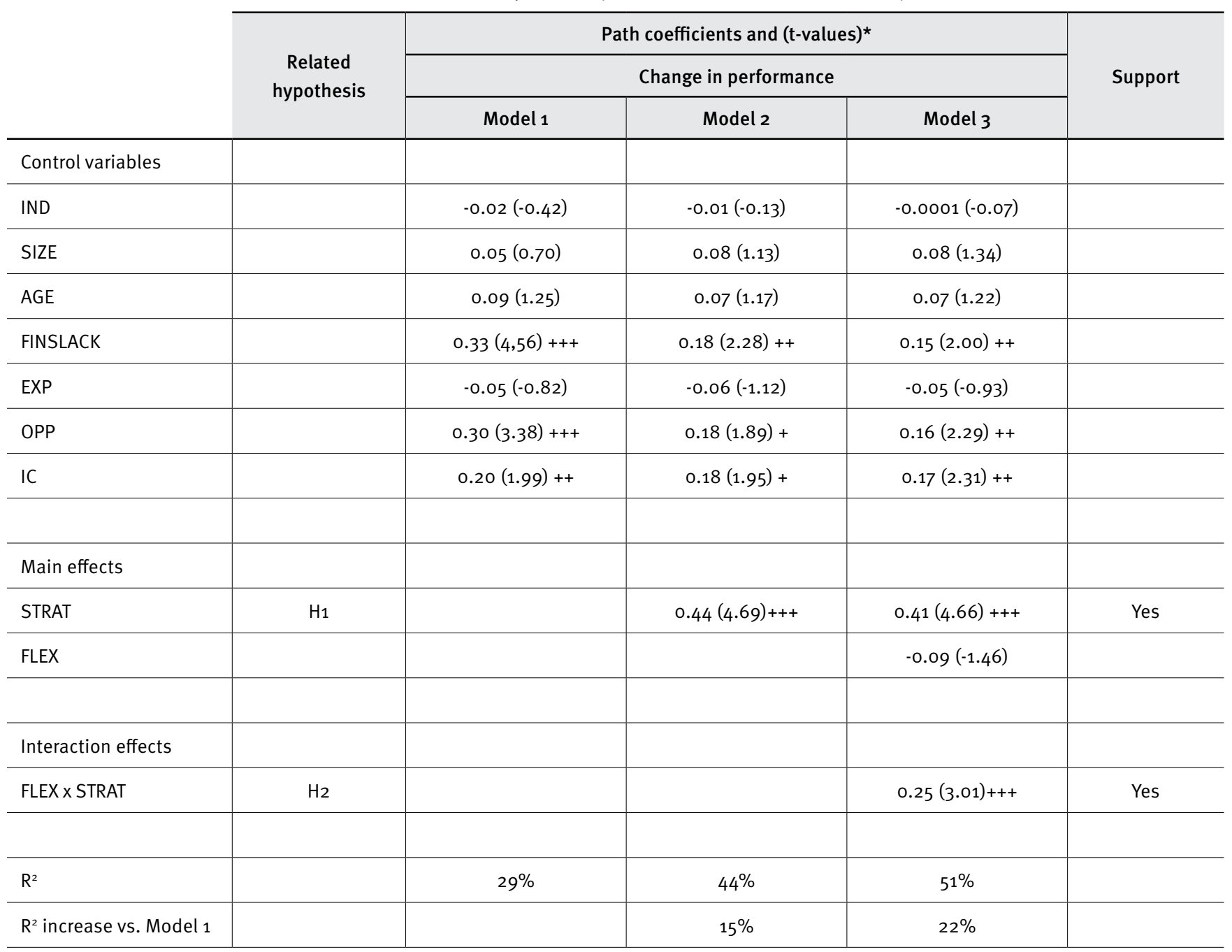

* Calculations based on path weighting scheme, bootstrapping with 1,000 samples or more and individual sign changes.

+ significant at $10 \%$.

++ significant at $5 \%$.

+++ significant at $1 \%$.

The second set of analyses, shown in Table 6, addresses firms' characteristics and capabilities that influence the choice for counter-cyclical strategies. Model 1 considers the direct effect of our control variables and is our starting point.

Model 2 adds the direct effect of our independent variable, opportunity recognition. It shows that opportunity recognition has positive, statistically significant path coefficients $(b=+0.14 ;+0.36 ;+0.28)$, confirming its positive effect on the choice of counter-cyclical strategy in supply, demand, and capital areas, respectively, which supports $\mathrm{H}_{3} \mathrm{a}, \mathrm{H}_{3} \mathrm{~b}$, and $\mathrm{H}_{3} \mathrm{c}$.

Model 3 adds our theorized indirect effects of entrepreneurial orientation. The $\mathrm{R}^{2}$ calculations at $21 \%, 28 \%$, and $20 \%$ indicate that our model is a reasonable predictor of the choice for counter-cyclical strategies in supply, demand, and capital ar- eas, respectively. Moreover, the respective $13 \%, 17 \%$, and $5 \%$ increases in $\mathrm{R}^{2}$ versus Model 1 indicate that our theorized variables in conjunction offer important contribution to those predictions.

Model 3 also shows EO's moderating effects on the relationship between opportunity recognition and choice for counter-cyclical strategies, which are complex. For demand $(b=+0.20)$ and supply ( $b=+0.18)$ strategies, the path coefficients are positive and significant at $5 \%$ and $10 \%$ levels, respectively. These results confirm that increased EO strengthens the positive effect of opportunity recognition on the choice for these counter-cyclical strategies in demand and supply, representing strong support for $\mathrm{H}_{4} \mathrm{~b}$ and moderate support for $\mathrm{H}_{4} \mathrm{a}$. For capital strategy, however, the coefficient $(b=-0.24)$ is negative, contrary to our expectation. Thus, there is no support for $\mathrm{H}_{4} \mathrm{C}$. 
Table 6. Results of the PLS structural model analysis - dependent variable: strategy

\begin{tabular}{|c|c|c|c|c|c|c|c|c|c|c|c|}
\hline & \multirow{3}{*}{$\begin{array}{c}\text { Related } \\
\text { hypothesis }\end{array}$} & \multicolumn{9}{|c|}{ Path coefficients and (t-values)* } & \multirow{3}{*}{ Support } \\
\hline & & \multicolumn{9}{|c|}{ Strategy } & \\
\hline & & \multicolumn{3}{|c|}{ Model 1} & \multicolumn{3}{|c|}{ Model 2} & \multicolumn{3}{|c|}{ Model 3} & \\
\hline \multicolumn{12}{|c|}{ Control variables } \\
\hline IND & & $(-1 \cdot 71)+$ & $(0.07)$ & $(1.50)$ & $(-1.87)+$ & $(-0.33)$ & $(1.37)$ & $(-1 \cdot 71)+$ & $(0.18)$ & $(1.44)$ & \\
\hline
\end{tabular}

\begin{tabular}{|c|c|c|c|c|c|c|c|c|c|}
\hline SIZE & 0.00 & 0.01 & 0.04 & -0.03 & -0.07 & -0.05 & -0.03 & -0.09 & -0.06 \\
\hline \multirow[t]{2}{*}{ AGE } & 0.07 & 0.09 & 0.12 & 0.02 & -0.01 & 0.09 & -0.01 & -0.05 & 0.07 \\
\hline & (1.16) & $(1.25)$ & $(1.76)+$ & (0.64) & $(-0.01)$ & $(1.15)$ & $(-0.12)$ & $(-0.82)$ & (1.14) \\
\hline
\end{tabular}

\begin{tabular}{c|c|c|c|c|c|c|c|c|c|c|c}
\hline FINSLACK & & 0.33 & 0.31 & 0.23 & 0.33 & 0.29 & 0.18 & 0.32 & 0.28 & 0.18 & \\
\hline & & $(3.46)+++$ & $(3.26)+++$ & $(2.63)+++$ & $(3.27)+++$ & $(3.14)+++$ & $(2.48)++$ & $(3.61)+++$ & $(3.46)+++$ & $(2.26)++$ & \\
\hline
\end{tabular}

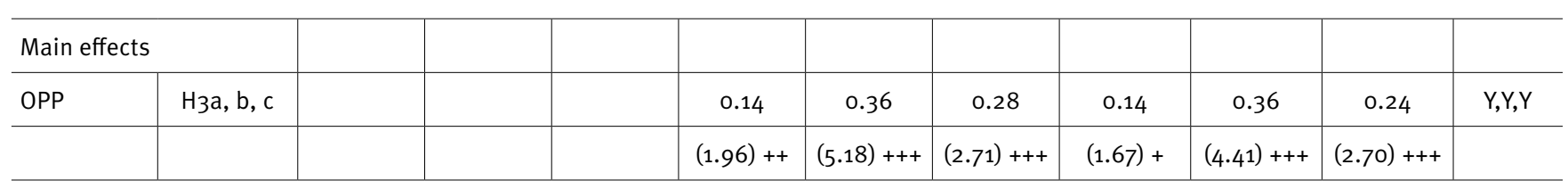

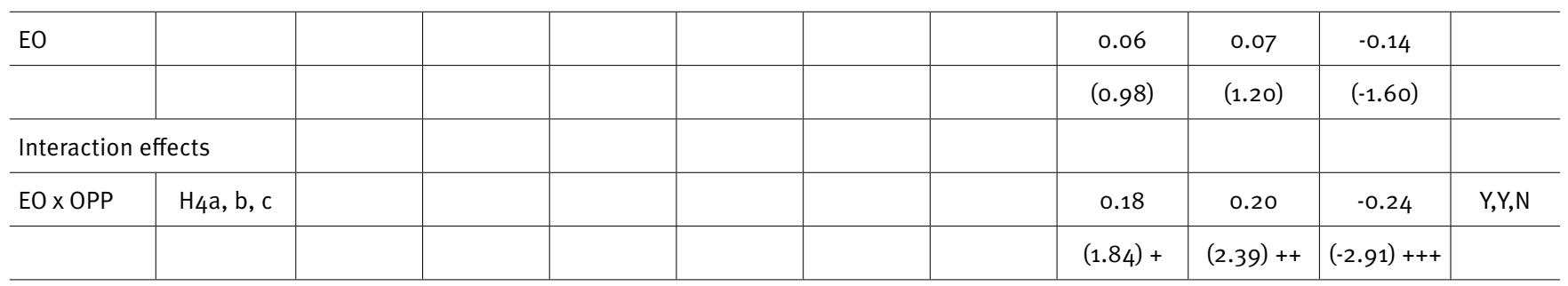

\begin{tabular}{|c|c|c|c|c|c|c|c|c|c|}
\hline $\mathrm{R}^{2}$ & $8 \%$ & $11 \%$ & $15 \%$ & $13 \%$ & $24 \%$ & $17 \%$ & $21 \%$ & $28 \%$ & $20 \%$ \\
\hline
\end{tabular}

* Calculations based on path weighting scheme, bootstrapping with 1,000 samples or more and individual sign changes.

+ significant at $10 \%$.

++ significant at $5 \%$.

+++ significant at $1 \%$.

\section{DISCUSSION}

Our results indicate that the majority of Brazilian firms in our sample pursued a pro-cyclical strategy of reductions in supply-related areas, particularly decreasing purchases and cutting personnel, but also reducing production. In most cases, reductions were small, probably because the recession in Brazil, although deep, lasted only two quarters and might have been over before firms 
took extreme measures. For instance, raw material supplies are usually ordered in advance, and it is reasonable to continue producing while inventories are high. Moreover, management may go through long processes before deciding to make cuts.

Most commonly, Brazilian firms made no change in capitaland demand-related areas, although pro-cyclical investments reductions were reported by several firms and were more common than counter-cyclical increases. Again, reductions were small, except for fixed assets and acquisitions, to which larger reductions were reported. The likely reason is that assets involved in these reductions are expensive, so each individual cut is significant. Institutional theory (DiMaggio \& Powell, 1983) may provide an explanation for this lack of response. Under uncertainty, firms wait to see what others will do and imitate them, creating a situation of isomorphism in which none of the players take initiative for a first move.

Few firms have adopted counter-cyclical strategies of increased investments during the recession; they generally experienced small increases in demand-related areas, most commonly in the form of a price increase, confirming the mixed results in the literature. Certain characteristics of firms increase the likelihood of a choice for counter-cyclical investments.

The first characteristic is an ability to recognize opportunities in recessions, which has a strong, positive effect on the choice of counter-cyclical strategies in supply $\left(\mathrm{H}_{3} \mathrm{a}\right)$, demand $\left(\mathrm{H}_{3} \mathrm{~b}\right)$, and capital $\left(\mathrm{H}_{3} \mathrm{c}\right)$. Firms whose employees have mindsets that foster identification of opportunities rather than only threats during recessions find new projects in which to invest.

This effect is moderated by the second characteristic: entrepreneurial orientation. In general, higher EO strengthens the positive effect of opportunity recognition on the likelihood of counter-cyclical investments in recessions. That happens because entrepreneurially oriented firms are proactive and accept changes and risks associated with such investments. Thus, the more a firm is entrepreneurially oriented, the more it will be willing to counter-cyclically invest and seize these recognized opportunities. This strengthening effect is substantial in demand-related areas $\left(\mathrm{H}_{4} \mathrm{~b}\right)$ and medium in supply-related areas $\left(\mathrm{H}_{4} \mathrm{a}\right)$. However, EO weakens the effect of opportunity recognition in capital-related areas, against $\mathrm{H}_{4} \mathrm{C}$. A possible explanation is that with limited resources, firms become selective and may invest in demand- and supply-related areas at the expense of capital projects. Indeed, less than half the respondents mentioned changes in capital-related strategy. In addition, capital investments like fixed assets and acquisitions are more complex and expensive and take longer, being less associated with the quickness demanded by entrepreneurial orientation.

Our results also indicate that counter-cyclical strategies of increased investments during recessions enable superior perfor- mance $\left(\mathrm{H}_{1}\right)$. This is a confirmation that the benefits of acquiring good-quality resources available at low prices during recessions more than offset the high risks of such a strategy. This positive effect of counter-cyclical strategy on performance is even stronger if the firm is flexible $\left(\mathrm{H}_{2}\right)$, as flexibility allows relocation and reconfiguration of resources so that implementation of investments will be more efficient, generating improved results.

It would sound strange to propose that firms counter-cyclically increase spending when cash is limited. The key to resolving this dilemma is finding the right investment opportunities. Recessions certainly create opportunities and it is worthwhile to look for them. Firms need to find ways to reduce costs in some - but not all - areas to improve efficiency while investing in the most promising projects.

\section{Limitations and future research}

We see several limitations to our study. A first limitation refers to the timing of performance we have measured. We have focused on immediate returns to fill a gap from prior studies, which mostly measured performance after the recession. However, some investments have lagged effects and related profits may take a long time to materialize. Likewise, cost cuts may be constrained by long-term contracts. The effects of some responses might be felt only after the downturn ends. Another limitation is survival bias, in line with Grewal \& Tansuhaj (2001) and most research on recessions. Our survey was conducted three years after the worst quarter of the recession, when some firms might have closed.

Other limitations relate to our method. As in any non-experimental design, it is not possible to completely rule out endogeneity problems (Semadeni, Withers, \& Trevis Certo, 2013). Moreover, we may face a reverse causality problem: we relied on theory to argue that investments increased performance, but it could be the opposite - higher performance enabled investments. Similar to Navarro et al (2010), we can confirm only association between variables, not causality. Another limitation is our small sample. Even though PLS studies have been published with smaller samples and PLS is adequate for such cases (Ringle et al., 2012), our results should be considered more indicative than conclusive. Finally, our sample included only firms operating in Brazil. This is an interesting context for such research, but caution is recommended before generalizing results to very different business environments.

This last limitation offers an interesting area for future research. Drawing on Srinivasan et al (2011), scholars could investigate whether specific characteristics of certain countries influence the choice for and success of counter-cyclical investments during recessions. For instance, emerging countries' dynamic environments (Hoskisson, Wright, Filatotchev, \& Peng, 2013) ex- 
pose firms to turbulence and may allow them to be more flexible than firms from developed economies. Furthermore, countries whose cultures are marked by tolerance for risk may have firms with higher entrepreneurial orientation.

\section{Contributions and conclusion}

By investigating the cyclical strategies that enable firms superior performance in recessions, our paper advances the business cycle management literature, an unexplored research stream within strategic management. In particular, we answer a call to address how firms absorb and respond to economic downturns and to use surveys to examine organizational factors that influence investment preferences in these moments (Srinivasan et al., 2011; Zona, 2012). To our knowledge, this is the first study to propose and test an integrative model with several variables to analyze recessions. Moreover, we do so in less traditional contexts proposed by some authors, such as non-listed companies (Mascarenhas \& Aaker, 1989).

Our research is also relevant to practitioners. Once in a recession, managers can implement our suggestions to make investments that will enable their firms to navigate through difficult periods. Furthermore, considering that recessions are recurring events, managers can invest in developing the characteristics and capabilities that will help their firms be prepared for future recessions.

To conclude, our research has indicated that most firms pro-cyclically reduce costs and investments during recessions. Nevertheless, firms with better ability to recognize opportunities in the changing environment and more entrepreneurial orientation to invest in these opportunities adopt a counter-cyclical strategy of investing in new projects, and present superior performance. Finally, it is important for firms to be flexible for an efficient implementation of these investments.

\section{ACKNOWLEDGMENTS}

We acknowledge the financial support received from Capes, CNPq and from FGV-Ebape/ Pró-Pesquisa for our research.

\section{NOTE FROM RAE}

A preliminary version of this article was presented in the $8^{\text {th }}$ Iberoamerican Academy Conference - World in Transition: business, multiculturalism and society on December 2013, promoted by Fundação Getulio Vargas/ Escola de Administração de Empresas de São Paulo (FGV/ EAESP)

\section{REFERENCES}

Aaker, D., \& Mascarenhas, B. (1984). The need for strategic flexibility. Journal of Business Strategy, 5(2), 74-82.

Anderson, B., Covin, J., \& Slevin, D. (2009). Understanding the relationship between entrepreneurial orientation and strategic learning capability: an empirical investigation. Strategic Entrepreneurship Journal, 3(3), 218-240.

Ang, S., Leong, S., \& Kotler, P. (2000). The Asian apocalypse: crisis marketing for consumers and business. Long Range Planning, 33(1), 97-119.

Apaydın, F. (2011). Changes in marketing strategies and performance outcomes of Turkish firms in 2008 global economic recession. International Business Research, 4(4), 104-114.

Beaver, G. (2002). The financial performance of smaller companies: observations from difficult times. Strategic Change, 11(1), 1-5.

Bromiley, P., Navarro, P., \& Sottile, P. (2008). Strategic business cycle management and organizational performance: a great unexplored research stream. Strategic Organization, 6(2), 207-219.

Campello, M., Graham, J., \& Harvey, C. (2010). The real effects of financial constraints: evidence from a financial crisis. The Journal of Financial Economics, 97(3), 470-487.

Claessens, S., \& Kose, M. (2009). Back to basics: what is a recession? Finance and Development, 45(1), 1-3.

Covin J., \& Slevin D. (1989). Strategic management of small firms in hostile and benign environments. Strategic Management Journal, 10(1), 75-87.

Crossland, C., \& Hambrick, D. (2011). Differences in managerial discretion across countries: how nation-level institutions affect the degree to which CEOs matter. Strategic Management Journal, 32(8), 797-819.

Crotty, J. (2009). Structural causes of the global financial crisis: a critical assessment of the "new financial architecture". Cambridge Journal of Economics 33(4), 563-580.

DiMaggio, P., \& Powell, W. (1983). The iron cage revisited: institutional isomorphism and collective rationality in organizational fields. American Sociological Review, 48(2), 147-160.

Dutt, P., \& Padmanabhan, V. (2011). Crisis and consumption smoothing. Marketing Science, 30(3), 491-512.

Dye, R., Sibony, O., \& Viguerie, S. (2009). Strategic planning: three tips for 2009. McKinsey Quarterly. Retrieved on June 28, 2013 from www. mckinsey.com/insights/strategy/strategic_planning_three_tips_for _2009.

Fornell, C., \& Larcker, D. (1981). Evaluating structural equation models with unobservable variables and measurement error. Journal of Marketing Research, 18(1), 39-50.

Franke, M., \& John, F. (2011). What comes next after recession? Airline industry scenarios and potential end games. Journal of Air Transport Management, 17(1), 19-26.

Galveas, E. (2009). Síntese da conjuntura - conjuntura 2008. Carta Mensal, 54(648), 83-94.

Geroski, P., \& Gregg, P. (1997). Coping with recession: U.K. firm performance in adversity. Cambridge, U.K.: Cambridge University Press.

Gertler, M., Kiyotaki, N., \& Queralto, A. (2012). Financial crises, bank risk exposure and government financial policy. Journal of Monetary Economics, 59(Supplement), S17-S34. 
Gore, C. (2010). The global recession of 2009 in a long-term development perspective. Journal of International Development, 22(6), 714-738.

Green, K., Covin, J., \& Slevin, D. (2008). Exploring the relationship between strategic reactiveness and entrepreneurial orientation: the role of structure-style fit. Journal of Business Venturing, 23(3), 356-383.

Grewal, R., \& Tansuhaj, P. (2001). Building organizational capabilities for managing economic crisis: the role of market orientation and strategic flexibility. Journal of Marketing, 65(2), 67-80.

Gruber, M., Heinemann, F., Brettel, M., \& Hungeling, S. (2010). Configurations of resources and capabilities and their performance implications: an exploratory study on technology ventures. Strategic Management Journal, 31(12), 1337-1356.

Grusky, D., Western, B., \& Wimer, C. (2011). The consequences of the great recession. In: Grusky, D, Western, B, Wimer, C. (eds). The Great Recession. New York: Sage, 3-20.

Gulati, R., Nohria, N., \& Wohlgezogen, F. (2010). Roaring out of recession. Harvard Business Review, 88(3), 1-8.

Gupta V., MacMillan I., \& Surie, G. (2004). Entrepreneurial leadership: developing and measuring a cross-cultural construct. Journal of Business Venturing, 19(2), 241-260.

Hair, J., Ringle, C., \& Sarstedt, M. (2011). PLS-SEM: indeed a silver bullet. Journal of Marketing Theory and Practice, 19(1), 139-151.

Hair, J., Ringle, C., \& Sarstedt, M. (2012). Partial least squares: the better approach to structural equation modeling? Long Range Planning, 45(56), 312-319.

Hall, R. (2005). Employment fluctuations with equilibrium wage stickiness. American Economic Review, 95(1), 50-65.

Hampson, D., \& McGoldrick, P. (2013). A typology of adaptive shopping patterns in recession. Journal of Business Research, 66(7), 831-838.

Hill, T., \& Mudambi, R. (2010). Far from Silicon Valley: how emerging economies are re-shaping our understanding of global entrepreneurship. Journal of International Management, 16(4), 321-327.

Hoskisson, R., Wright, M., Filatotchev, I., \& Peng, M. (2013). Emerging multinationals from mid-range economies: the influence of institutions and factor markets. Journal of Management Studies, 50(7), 1295-1321.

Hulland, J. (1999). Use of partial least square (PLS) in strategic management research: a review of four recent studies. Strategic Management Journal, 20(2), 195-204.

Ireland, R., Hitt, M., \& Sirmon, D. (2003). A model of strategic entrepreneurship: the construct and its dimensions. Journal of Management, 29(6), 963-989.

Ivashina, V., \& Scharfstein, D. (2010). Bank lending during the financial crisis of 2008. Journal of Financial Economics, 97(3), 319-338.

Kamakura, W., \& Du, R. (2012). How economic contractions and expansions affect expenditure patterns. Journal of Consumer Research, 39(2), 229-247.

Kaytaz, M., \& Gul, M. (2014). Consumer response to economic crisis and lessons for marketers: the Turkish experience. Journal of Business Research. Journal of Business Research, 67(1), 2701- 2706.

Lamey, L., Deleersnyder, B., Steenkamp, J., \& Dekimpe, M. (2012). The effect of business-cycle fluctuations on private label share: what has marketing conduct got to do with it? Journal of Marketing, 76(1), 1-19.

Latham, S., \& Braun, M. (2008). The performance implications of financial slack during economic recession and recovery: observations from the software industry (2001-2003). Journal of Managerial Issues, 20(1), 30-52.
Latham, S., \& Braun, M. (2011). Economic recessions, strategy, and performance: a synthesis. Journal of Strategy and Management, 4(2), 96-115.

Li, S., \& Tallman, S. (2011). MNC strategies, exogenous shocks, and performance outcomes. Strategic Management Journal, 32(10), 1119-1127.

Lumpkin, G., \& Dess, G. (1996). Clarifying the entrepreneurial orientation construct and linking it to performance. Academy of Management Review, 21(1), 135-172.

Ma, X., Yiu, D., \& Zhou, N. (2014). Facing global economic crisis: foreign sales, ownership groups, and corporate value. Journal of World Business, 49(1), 87-100.

Mansoor, D., \& Jalal, A. (2011). The global business crisis and consumer behavior: Kingdom of Bahrain as a case study. International Journal of Business and Management, 6(1), 104-115.

Mascarenhas, B., \& Aaker, D. (1989). Strategy over the business cycle. Strategic Management Journal, 10(3), 199-210.

McGahan, A. (2004). How industries evolve: principles for achieving and sustaining superior performance. Boston, MA: Harvard Business School Press.

McGrath, R. (1999). Falling forward: real options reasoning and entrepreneurial failure. Academy of Management Review, 24(1), 13-30.

McGrath, R., \& MacMillan, I. (2000). The entrepreneurial mindset: strategies for continuously creating opportunity in an age of uncertainty. Boston, MA: Harvard Business School Press.

Muurlink, P., Wilkinson, A., Peetz, D., \& Townsend, K. (2012). Managerial autism: threat-rigidity and rigidity's threat. British Journal of Management, 23(Supplement), S74-S87.

Nadkarni, S., \& Narayanan, V. (2007). Strategic schemas, strategic flexibility, and firm performance: the moderating role of industry clockspeed. Strategic Management Journal, 28(3), 243-270.

Navarro, P., Bromiley, P., \&Sottile, P. (2010). Business cycle management and firm performance: tying the empirical knot. Journal of Strategy and Management, 3(1), 50-71.

Nunes, J., Drèze, X., \& Han, Y. (2010). Conspicuous consumption in a recession: toning it down or turning it up? Journal of Consumer Psychology, 21(2), 199-205.

Parnell, J., Dent., E, O’Regan, N., \& Hughes, T. (2012). Managing performance in a volatile environment: contrasting perspectives on luck and causality. British Journal of Management, 23(Supplement), S104-S118.

Plambeck, N., \& Weber, K. (2010). When the glass is half full and half empty: CEO's ambivalent interpretations of strategic issues. Strategic Management Journal, 31(7), 689-710.

Pochmann, M. O. (2009). Trabalho na crise econômica no Brasil: primeiros sinais. Estudos Avançados, 23(66), 41-52.

Podsakoff, P. M., MacKenzie, S. B., \& Podsakoff, N. P. (2012). Sources of method bias in social science research and recommendations on how to control it. Annual Review of Psychology, 63, 539-569.

Podsakoff, P. M., \& Organ, D. (1986). Self-reports in organizational research: problems and prospects. Journal of Management, 12(4), 531-544.

Porter, M. (1979). How competitive forces shape strategy. Harvard Business Review, 57(1), 66-75.

Ringle, C., Sarstedt, M., \& Straub, D. (2012). A critical look at the use of PLS-SEM in MIS quarterly. MIS Quarterly, 36(1), i3-14.

Ringle, C., Wende, S., \& Will, A. (2005). Smart PLS 2.0. Retrieved on April 15, 2013 from http://www.smartpls.de. 
Robins, J. (2012). Partial-least squares. Long Range Planning, 45(5-6), 309-311.

Rowe, W., \& Wright, P. (1997). Related and unrelated diversification and their effect on human resource management controls. Strategic Management Journal, 18(4), 329-338.

Schotter, A., \& Beamish, P. (2013). The hassle factor: an explanation for managerial location shunning. Journal of International Business Studies, 44(5), 521-544.

Semadeni, M., Withers, M. C., \& Trevis Certo, S. (2014). The perils of endogeneity and instrumental variables in strategy research: understanding through simulations. Strategic Management Journal, 35(7), 1070-1079.

Siemsen, E., Roth, A., \& Oliveira, P. (2010). Common method bias in regression models with linear, quadratic, and interaction effects. Organizational Research Methods, 13(3), 456-476.

Srinivasan, R., Lilien, G., \& Sridhar, S. (2011). Should firms spend more on research and development and advertising during recessions? Journal of Marketing, 75(3), 49-65.

Srinivasan, R., Rangaswamy, A., \& Lilien, G. (2005). Turning adversity into advantage: does proactive marketing during a recession pay off. International Journal of Research in Marketing, 22(2), 109-125.

Tellis, G., \& Tellis, K. A. (2009). Research on advertising in a recession: a critical review and synthesis. Journal of Advertising Research, 49(3), 304-327.

Tsang, E. (2002). Acquiring knowledge by foreign partners from international joint ventures in a transition economy: learning-by-doing and learning myopia. Strategic Management Journal, 23(9), 835-854.
Verdú-Jover, A, Lloréns-Montes, F., \& García-Morales, V. (2006). Environment-flexibility coalignment and performance: an analysis in large versus small firms. Journal of Small Business Management, 44(3), 334-349.

Venaik, S., Midgley, D., \& Devinney, T. (2005). Dual paths to performance: the impact of global pressures on MNC subsidiary conduct and performance. Journal of International Business Studies, 36(6), 655-675.

Wang, C. (2008). Entrepreneurial orientation, learning orientation, and firm performance. Entrepreneurship Theory and Practice, 32 (4), 635-657.

Worren N., Moore, K., \& Cardona, P. (2002). Modularity, strategic flexibility, and firm performance: a study of the home appliance industry. Strategic Management Journal, 23(12), 1123-1140.

Wright, M., Hoskisson, R., Busenitz, L., \& Dial, J. (2000). Entrepreneurial growth through privatization: the upside of management buyouts. The Academy of Management Review, 25(3), 591-601.

Zarnowitz, V. (1985). Recent work on business cycles in historical perspective: a review of theories and evidence. Journal of Economic Literature, 23(2), 523-580.

Zhou, K., \& Wu, F. (2010). Technological capability, strategic flexibility, and product innovation. Strategic Management Journal, 31(5), 547-561.

Zona, F. (2012). Corporate investing as a response to economic downturn: prospect theory, the behavioural agency model and the role of financial slack. British Journal of Management, 23(Supplement), S42-S57.

Zurawicki, L., \& Braidot, N. (2005). Consumers during crisis: responses from the middle class in Argentina. Journal of Business Research, 58(8), 1100-1109. 